\title{
The Role of Nucleophosmin 1 (NPM1) Mutation in the Diagnosis and Management of Myeloid Neoplasms
}

\author{
Katalin Kelemen
}

Citation: Kelemen, K. The Role of Nucleophosmin 1 (NPM1) Mutation in the Diagnosis and Management of Myeloid Neoplasms. Life 2022, 12, 109. https://doi.org/10.3390/ life12010109

Academic Editor: Daniele Focosi

Received: 6 December 2021

Accepted: 11 January 2022

Published: 13 January 2022

Publisher's Note: MDPI stays neutral with regard to jurisdictional claims in published maps and institutional affiliations.

Copyright: (C) 2022 by the author. Licensee MDPI, Basel, Switzerland. This article is an open access article distributed under the terms and conditions of the Creative Commons Attribution (CC BY) license (https:// creativecommons.org/licenses/by/ $4.0 /)$.
Department of Laboratory Medicine and Pathology, Mayo Clinic, Phoenix, AZ 85054, USA; Kelemen.katalin@mayo.edu

\begin{abstract}
Nucleophosmin (NPM1) is a multifunctional protein with both proliferative and growthsuppressive roles in the cell. In humans, NPM1 is involved in tumorigenesis via chromosomal translocations, deletions, or mutation. Acute myeloid leukemia (AML) with mutated NPM1, a distinct diagnostic entity by the current WHO Classification of myeloid neoplasm, represents the most common diagnostic subtype in AML and is associated with a favorable prognosis. The persistence of NPM1 mutation in AML at relapse makes this mutation an ideal target for minimal measurable disease (MRD) detection. The clinical implication of this is far-reaching because NPM1-mutated AML is currently classified as being of standard risk, with the best treatment strategy (transplantation versus chemotherapy) yet undefined. Myeloid neoplasms with NPM1 mutations and $<20 \%$ blasts are characterized by an aggressive clinical course and a rapid progression to AML. The pathological classification of these cases remains controversial. Future studies will determine whether NPM1 gene mutation may be sufficient for diagnosing NPM1-mutated AML independent of the blast count. This review aims to summarize the role of NPM1 in normal cells and in human cancer and discusses its current role in clinical management of AML and related myeloid neoplasms.
\end{abstract}

Keywords: nucleophosmin 1 (NPM1); mutation; myeloid neoplasm; acute myeloid leukemia; minimal residual disease (MRD)

\section{Introduction}

Nucleophosmin (NPM1), also called B23 or numatrin, is a phosphoprotein expressed at high levels in the granular region of the nucleolus [1,2]. NPM1 is a multifunctional protein that is involved in many cellular activities that may be related to both proliferative and growth-suppressive roles in the cell. The human NPM1 cDNA encoding a 294-amino acid protein was cloned in 1989 [3]. In mice, inactivation of the NPM1 results in gene developmental defects and embryonic lethality at mid-gestation [4]. In humans, on the other hand, NPM1 is involved in tumorigenesis. The NPM1 gene can undergo a variety of genetic alterations, explaining its contributions to molecular pathogenesis of tumors of diverse histological origins. Genetic changes of the NPM1 gene include chromosomal rearrangements and deletions in various hematological and solid tumors. The mutation of NPM1 plays a unique role in the pathogenesis of acute myeloid leukemia (AML) and is seen in about 35\% of AML patients [5], which makes NPM1-mutated AML the single largest unique group of AML. NPM1 has a greatly heterogeneous role in the cell and interacts with both oncogenic and tumor-suppressing cellular functions.

\section{NPM1 Protein in the Normal Cell}

In the normal cell, NPM1, an abundant phosphoprotein of $37 \mathrm{kDa}$ that is highly concentrated in the nucleolus, shuttles rapidly between the nucleus and the cytoplasm [6,7]. The shuttling activity and proper subcellular localization of NPM1 is crucially important for normal cell function. By shuttling between cellular compartments, NPM1 participates in a multitude of cellular processes, including transport of pre-ribosomal particles, ribosome 
biogenesis, response to stress stimuli such as UV radiation and hypoxia, regulation of chromatin condensation and decondensation, which has a crucial effect on DNA transcription and DNA repair, and interactions with tumor suppressors $p 53$ and ARF.

Within the structure of NPM1 protein, several functional domains account for various biochemical functions (Figure 1).

Nucleophosmin-1 polypeptide chain functional domains

294 amino acids

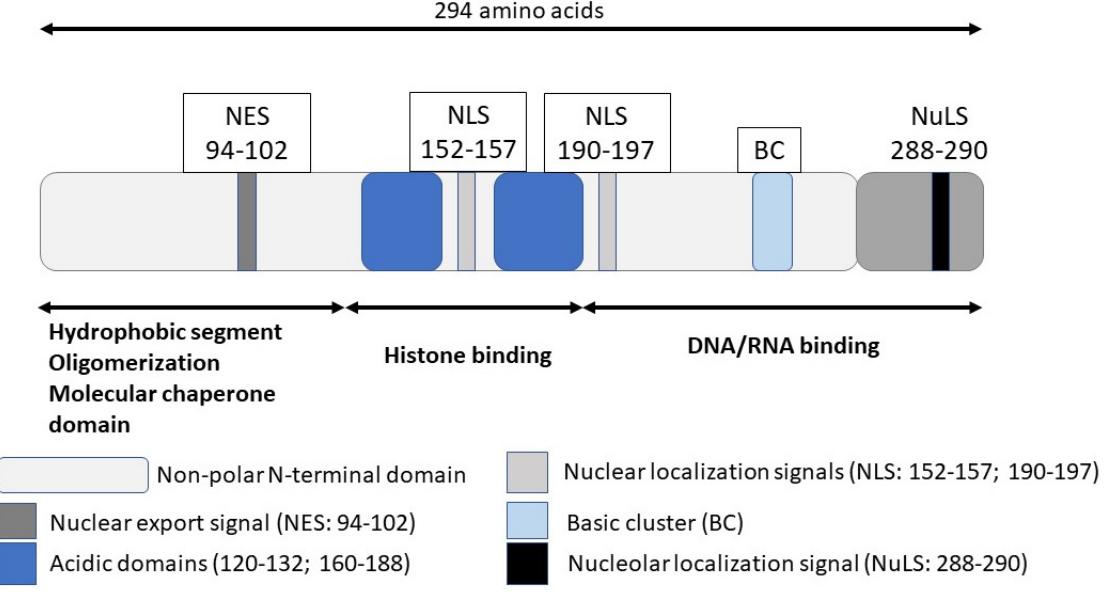

Figure 1. NPM1 polypeptide functional domains.

The N-terminal region carries a conserved non-polar sequence, with an important role as chaperone for proteins and nucleic acids [8-10]. In fact, all members of the family of nucleophosmins (Np) share this conserved region. This domain enables NPM1's various functions, in addition to being a molecular chaperone. It can contribute to oligomerization, histone binding, nucleosome assembly, and acetylation-dependent transcription [11,12]. In addition to the N-terminal domain, different molecular domains are responsible for DNA/RNA binding functions. Various localization signals recognized within NPM1 include the nuclear export signal, the bipartite nuclear localization signal, and the nucleolar localization signal (Figure 1). The nucleolar localization signal (NuLS) is primarily responsible for anchoring NPM1 to the nucleolus, and it is dependent on the presence of two tryptophans at the C-terminus localized at W288 and W290, respectively [13,14]. Through these various domains, NPM1 can interact with many partners, such as nucleolar factors (nucleolin, fibrillarin), transcription factors (interferon regulatory factor 1 (IRF1), nuclear factor kappa B (NFkB)), histones (H3, H4, and H2B), proteins and enzymes (DNA polymerase-alpha), proteins of mitosis (NUMA), and proteins that respond to oncogenic stress (p53, ARF). NPM1 can associate with DNA [15] and RNA [10] and has endoribonuclease activity especially to ribosomal RNA (rRNA) [16]. The multitude of cellular activities NPM1 can interact with explains how NPM1 can exhibit both oncogenic and tumor-suppressor functions in the cell. Of the two existing alternatively spliced isoforms of NPM1 (B23.1 and B23.2), B23.1 is the more prevalent variant [17,18]. In the normal cell, NPM1 exists predominantly as an oligomer [19] and less commonly in the form of pentamers and decamers [20].

\section{NPM1 in Human Cancer}

The role of NPM1 in human cancer is remarkable for its involvement in tumors of diverse histological origins. At least three well-characterized genetic mechanisms can contribute: overexpression of the NPM1 protein, chromosomal translocations resulting in fusion products with NPM1, or mutation of the NPM1 gene. In addition, NPM1 maps to the 5 q35 locus of chromosome 5, a region that is deleted in a subset of patients with de novo myelodysplastic syndromes (MDS). The partial or complete loss of chromosome 5 is 
also commonly observed in therapy-related MDS. The specific role of NPM1 is yet to be explored in these subsets of MDS.

NPM protein is known to be overexpressed in various tumors, including carcinomas of gastric [21], colonic [22], ovarian [23], and prostate [24] origin. Overexpression of NPM1 mRNA has been shown to be an independent marker of recurrence and progression of bladder carcinoma [25].

On the other hand, chromosomal translocation and mutation of the NPM1 gene are common genomic alterations in both lymphoid and myeloid hematologic neoplasms [26-29], with NPM1 mutation being essentially unique to AML [5]. Chromosomal translocations may result in oncogenic fusion proteins, such as $N P M-A L K$ in anaplastic large cell lymphoma, $N P M-R A R \alpha$ (retinoic acid alpha) in acute promyelocytic leukemia (APL), and NPM-MLF1 (myelodysplasia/myeloid leukemia factor 1) in MDS and AML. The mutant NPM1 in AML leads to abnormal subcellular localization of the protein in the cytoplasm. A common feature in both mechanisms is the reduction in the total amount of NPM1 protein due to decrease in NPM1 dosage, secondary to heterozygosity. The decreased dosage of NPM1 could be potentially augmented if a negative-dominant effect of the mutated protein exists over the wild-type protein.

The different mechanisms described above do not necessarily identify whether NPM1 will function as an oncogene, a tumor suppressor, or both in any specific scenario. The role of NPM1 as a proto-oncogene is supported by the observation that cancer cells in the phase of growth and proliferation overexpress NPM1, and at the same time, apoptosis is inhibited. The level of NPM1 protein is higher in proliferating and cancerous cells than in quiescent cells [30]. This mechanism may include the effect of the MYC oncogene, since MYC is one of the regulators of NPM1 transcription [31,32], or the stimulation of DNA polymerase-alpha activity by NPM1 [33]. Although there are various mechanisms, evidence supports that the main role of NPM1 in supporting cell growth relates to its role in the synthesis of ribosomes. The ability of NPM1 protein to bind nucleic acids [15,34], to act as a nuclear-cytoplasmic shuttle [6,7], and transport pre-ribosomal particles [35,36] designate NPM1 as one of the most important contributors in ribosome assembly. Thus, it is possible that the overexpression of NPM1 in cancer cells increases cell growth and proliferation primarily by providing ribosomes. Another important mechanism is related to inhibition of pro-apoptotic pathways by NPM1 through various indirect mechanisms, such as increased DNA repair, upregulation of proliferating cellular nuclear antigen (PCNA), which is an essential component of DNA repair activity, and downregulation of the tumor suppressor IRF1 [37]. These mechanisms were demonstrated in studies performed on NIH3 T3 fibroblasts that exhibited resistance to UV-induced apoptosis due to overexpressed NPM1 [37]. In summary, NPM1 has various options for promoting tumor genesis and function as a proto-oncogene.

Can NPM1 function as a tumor-suppressor gene? NPM1 protein stabilizes ARF by binding to it inside the nucleolus and thus inhibiting its degradation [38,39]. The overexpression of exogeneous NPM1 has been shown to stabilize ARF [39]. On the other hand, ARF has been shown to inhibit nuclear to cytoplasmic shuttling of NPM1 [40]. These observations indicate that NPM1 may be an important contributor to the ARFmediated regulation of oncogenic stress, and as such, it could be considered as a tumor suppressor. Furthermore, increasing evidence suggests that during cellular stress, such as UV irradiation, NPM1 increases the stability of p53 by binding to MDM2 [41], a p53-specific ubiquitin ligase that mediates p53 decay [42]. The interaction between NPM1 and p53 may also take place downstream of p53-for example, by engaging GADD45a, a proapoptotic protein that is responsive to genotoxic stress. NPM1 directly binds to GADD45a and regulates its cellular localization [43]. Finally, NPM1 may have a role in the preservation of DNA stability via various molecular pathways, including the improving of the DNA repair process [44]. NPM1 is present in the centrosome and represents one of the substrates of CDK2-cyclin E complex [45]; thus, it contributes to the stabilization and regulation of mitosis. Cells of NPM1 haploinsufficient mice $(\mathrm{Npm}+/-)$ show increased genomic 
instability and increased susceptibility to oncogenic transformation [4]. In summary, NPM1 has a capability to act either as a tumor suppressor or a proto-oncogene, and its actual role may be determined by the balance between its various molecular partners and the level of NPM1 expression (Figure 2).

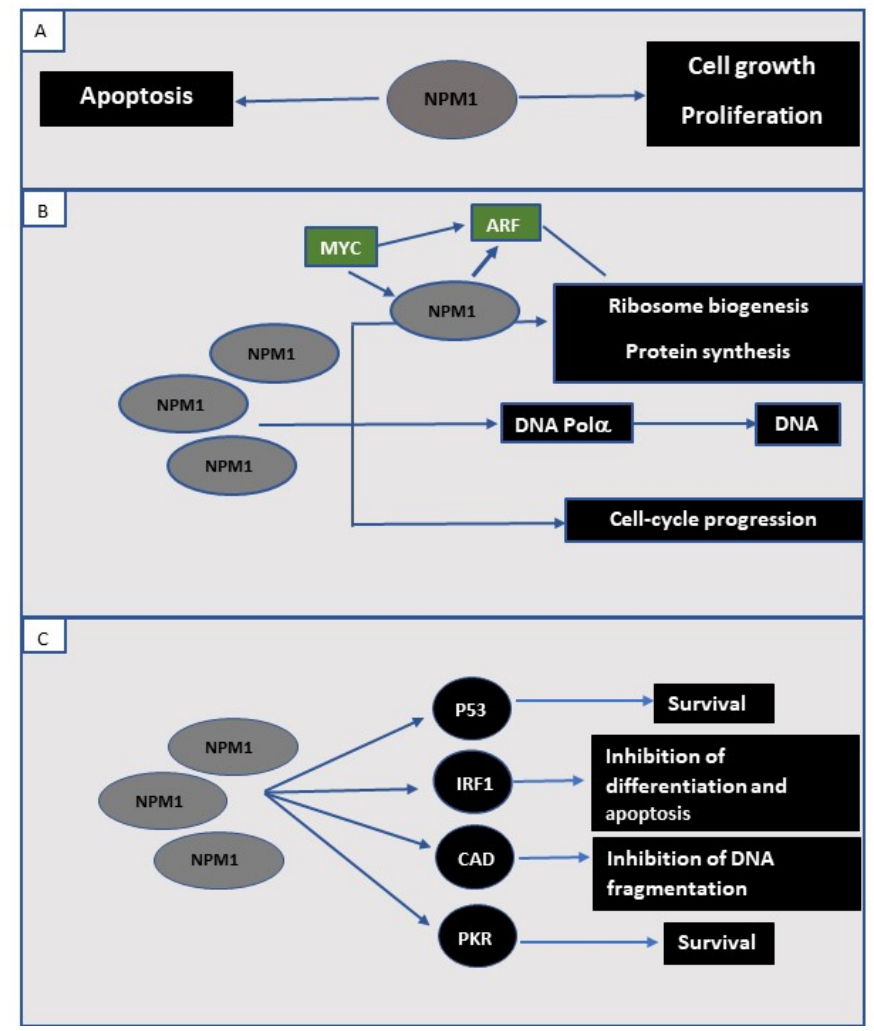

Figure 2. The effect of NPM1 overexpression in tumor cells. (A) In normal wild-type tissues, where a balance between cell proliferation and apoptosis is maintained, the expression of NPM1 protein is normal. In cancer cells, NPM1 is overexpressed and exhibits a proto-oncogenic effect by simultaneous stimulation of cell proliferation (B) and inhibition of apoptosis (C). A major contribution of NPM1 overexpression to cell growth and proliferation is the increasing ribosome biogenesis. NPM1 and several other ribosomal proteins respond to transcriptional regulation by MYC. Ribosome biogenesis is not the only mechanism since NPM1 also supports cell-cycle progression in addition to stimulating DNA polymerase alpha (DNA Pol $\alpha$ ). (C) Anti-apoptotic properties of NPM1 overexpression manifest through several different mechanisms. The stabilization of p53 and the downregulation of the catalytic function of eukaryotic initiation factor 2 kinase PKR support cell survival. The prevention of the transcription factor interferon regulatory factor 1 (IRF-1) from binding DNA inhibits apoptosis. Inhibition of caspase-activated DNAse (CAD) prevents DNA fragmentation and eliminates its proapoptotic activity.

\subsection{Acute Myeloid Leukemia (AML) with Mutated NPM1; A Myeloid Neoplasm with Unique Features}

The role of NPM1 in human cancer has received a new spotlight with the discovery of mutations of exon 12 of NPM1 in approximately $30 \%$ of adult de novo AML, and in $50-60 \%$ in those with a normal karyotype $[46,47]$. The latest updates of the World Health Organization (WHO) classification of myeloid neoplasm recognized AML with mutated NPM1 as a distinct diagnostic entity [48].

While studying subcellular localization of NPM1 protein, Falini et al. observed a correlation between the presence of cytoplasmic NPM1 and certain clinical and biological features in AML [5]. In their study of 591 bone marrow samples of de novo AML, 35.2\% of patients showed cytoplasmic NPM1, while cytoplasmic NPM1 was not observed either in 135 secondary AMLs or in 980 neoplasms other than AML. From a morphologic point 
of view, cytoplasmic NPM1 was observed in a variety of morphologic subtypes spanning from M0 to M7. More importantly, most cases with cytoplasmic NPM1 exhibited a normal karyotype and a good initial response to induction chemotherapy. These cases also showed an association with increased frequency of FLT3 internal tandem duplication (FLT3-ITD) and lack of expression of CD34 and CD13 by flow cytometry [5].

It turns out that a novel mutation in exon 12 of the NPM1 gene results in cytoplasmic localization of NPM1. Several different types of mutations exist. The most common type (called type A), representing about $70-80 \%$ of all mutations, features a four base pair nucleotide (TCTG) insertion at the position encoding the 288th amino acid residue, resulting in a frame shift of the downstream sequence [49]. As a consequence, the C-terminal amino acid sequence 286DLWQWWRKSL-COOH changes to 286DLCLAVEEVSLRK-COOH. After type A mutation, types B and D are the most frequent, representing $12 \%$ and $4 \%$ of all mutations in one study, while all other mutation types are less than $1 \%$ each, respectively [49] (Table 1).

Table 1. Most common mutations of NPM1 in AML.

\begin{tabular}{|c|c|c|}
\hline Mutation & Sequence & $\begin{array}{l}\text { Predicted } \\
\text { Amino Acid }\end{array}$ \\
\hline Wild type (NPM 1.1) & GAT CTC TGG CAG TGG AGG AAG TCT CTT TAA GAAAATAG & -DLWOWRKSL \\
\hline Mutation A & 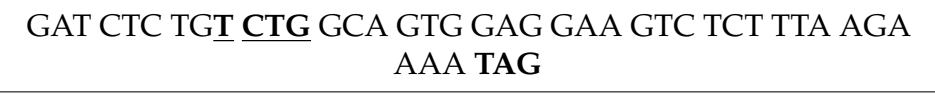 & -DLCLAㅌEEESSLRK \\
\hline Mutation B & $\begin{array}{c}\text { GAT CTC TGC } \underline{\text { ATG GCA GTG GAG GAA GTC TCT TTA AGA }} \\
\text { AAA TAG }\end{array}$ & -DLCMAㅌEE $\underline{\mathbf{L}} \underline{\mathbf{L} R K}$ \\
\hline Mutation D & $\begin{array}{c}\text { GAT CTC TGㅡ CTG GCA GTG GAG GAA GTC TCT TTA AGA } \\
\text { AAA TAG }\end{array}$ & -DLCLAㅌEEESSLRK \\
\hline
\end{tabular}

Though numerous different sequence mutations exist in the NPM1 gene (a total of 55 variants have been reported), all mutant proteins feature a critically important motif, notably the loss of at least one of W288 and W290, and they all share the last five amino acids [49]. Thus, despite the large number and variability of the mutations, all mutants invariably share a frame shift of the $\mathrm{C}$-terminus. The frame shift directly relates to the cytoplasmic localization. Nakagawa et al. recognized that the frame shift results in a loss of nucleolar localization signal (WXW) and in a gain of nuclear export signal (LXXXVXXVXL) [50]. Falini et al. further confirmed that both of these signal changes are necessary for the relocation of the mutant NPM protein from the nucleus to the cytoplasm [51]. The correlation between the cytoplasmic localization of NPM1 protein and the mutation is strong. At the original discovery of NPM1-mutated AML, it was the cytoplasmic staining of NPM1 that directed attention to a subgroup of AML that turned out to become the single largest subtype of AML defined by a mutation [5]. The predominantly cytoplasmic staining suggests that there is an interaction between the mutant NPM1 and the wild-type product that results in retaining both products in the cytoplasm via heterodimerization [52]. The results of the German AML Cooperative Group supported the findings of previous studies: NPM1 mutations were identified in 52.9\% of AML cases [53]. Their report also confirmed the frequent association of NPM1 mutations with FLT3 mutations and additionally reported that $M L L$ tandem duplication, NRAS, KIT, and CEBPA mutations were not common in NPM1-mutated AML [53]. There seems to be a bias in age distribution [49]. In AML patients younger than 35, NPM1 mutations were less frequent than in those who were older than 35 years. Subsequent studies continued to add further layers of observations. Verhaak et al. reported that NPM1-mutated AML, while associated with normal karyotype and FLT3 mutation is also associated with higher white blood cell counts [49]. In contrast 
with those patients with NPM1 and FLT3 mutations, NPM1-mutated AML patients without FLT3-ITD mutation represent a distinct subgroup of young adult patients with AML [54].

Of particular interest to diagnostic hematopathologists, multilineage dysplasia is observed quite frequently in bone marrow cells of AML with mutated NPM1, raising a differential diagnosis of AML with multilineage dysplasia [55]. It has become clear that in NPM1-mutated AML this type of dysplasia does not signify a worse prognosis and that the observation of dysplasia should not overwrite the diagnosis of AML with mutated NPM1 [55,56]. Another observation, potentially important for disease follow-up, is a remarkable stability of NPM1 mutations over time, reliably present at disease relapse and typically expressed across the entire leukemic population [14,46,57-59].

\subsection{Prognosis of NPM1-Mutated AML}

AML with mutated NPM1 typically shows a good response to induction chemotherapy [5]. Cases with a normal karyotype in the absence of an FLT3-ITD mutation have a favorable prognosis $[49,53,54,60-62]$. In young patients with a normal karyotype and no FLT3-ITD mutation, the prognosis is comparable with that of patients with AML with $\mathrm{t}(8 ; 21)(\mathrm{q} 22 ; \mathrm{q} 22.1)$ or AML with inv(16)(p13.1;q22) [54]. The presence of coexisting chromosomal abnormalities, observed in only $15 \%$ of patients, does not modify the prognostic effect of NPM1 mutations [54,63,64]. Additional molecular mutations, if present, especially those of FLT3, IDH1, IDH2, and DNMT3A genes, may significantly alter the prognosis [46]. Though it is clear that the presence of FLT3-ITD mutations negatively influence the prognosis, it is to be pointed out that in younger adult patients, the prognosis is still better than in those patients who have AML with FLT3-ITD and wild-type NPM1, especially when the FLT3-ITD mutation is present at a low allelic ratio [65-67]. In older patients (aged older than 70 years), the negative prognostic impact of a coexisting FLT3-ITD mutation in NPM1-mutated AML is less clear [68]. The least favorable outcomes have been observed in cases with concomitant mutations of NPM1, FLT3-ITD, and DNMT3A [69].

\section{Minimal Residual Disease (MRD) Monitoring in NPM1-Mutated AML}

Unlike many other myeloid associated mutations, NPM1 mutations are stable over time, usually documented at disease relapse and commonly expressed in the whole leukemic population [14,46,57-59]. Based on its homogeneous mutation pattern in AML, NPM1 mutation may be considered an ideal leukemia-specific target for minimal residual disease/minimal measurable disease (MRD) detection [70]. Since the first RQ-PCR-based assay applied by Gorello et al. [71], RQ-PCR based assays have proven themselves as a reliable system for quantitatively assessing NPM1-mutated gene copies [71-77]. MRD assays most commonly include primer designed to the NPM1 mutations type A, B, and D because these three mutations together represent the vast majority of AML cases (type A mutation represents $70-80 \%$ of all mutations, while types B and D together represent an additional 15-20\%) $[71,74,77]$. The consensus from the European Leukemia Network (ELN) MRD Working Party recommends that AML patients with NPM1 mutations undergo molecular MRD evaluation at the following clinical timepoints: at diagnosis, after 2 cycles of induction/consolidation chemotherapy, and at the end of treatment [78]. The selection of best sample - namely, bone marrow (BM) versus peripheral blood (PB)-remains controversial due to the observation that NPM1-mutated MRD may sometimes be undetectable in PB but that a BM sample shows detectable MRD at the end of treatment. Balsat et al. reported discordant results (a positive MRD in BM and negative result in PB) in $24.6 \%$ of cases [76]. Shayegi et al. reported differences between BM and PB MRD in 14.5\% of cases [79]. If such a discrepancy is detected, NPM1 MRD monitoring is recommended every 4 weeks for at least 3 months to evaluate for MRD increase [78]. Overall, the BM aspirate is generally accepted to be the best specimen for MRD evaluation [80].

NPM1 mutation levels at diagnosis as measured by RQ-PCR did not have an impact on complete remission (CR) rate after induction chemotherapy, and other survival measures such as event-free survival (EFS) and overall survival (OS) were not influenced either $[13,65,81,82]$. 
Conversely, as it has been demonstrated recently by Patel et al., high NPM1 variant allelic frequency (VAF) (>0.44) detected by next-generation sequencing (NGS) correlated with shortened median OS and shortened EFS. High NPM1-mutated allele burden at diagnosis by NGS was associated with unfavorable clinical outcomes [83]. This suggests that VAF determined by NGS may correlate better with a true clonal disease burden, which is different from the leukemic blast burden due to the multilineage presence of NPM1 mutations in the BM.

In NPM1-mutated AML patients who previously reached an MRD negative status, serial molecular MRD evaluation may offer the benefit of predicting an impending relapse $[80,84,85]$. It has been documented by several studies that the reoccurrence of NPM1 mutation may be documented as early as 2-3 months before a morphologic relapse becomes evident $[73,74,79,84,86-94]$. The median time from the detection of NPM1-mutated transcripts to the overt morphologic relapse was highly variable (median of 2.6 months, range 0.4 to 23.6 months) [91].

The role for allogeneic hematopoietic cell transplantation (allo-HSCT) in NPM1mutated AML is still controversial. The prognostic value of pretransplant NPM1-mutated MRD has been evaluated in several studies [76,92-97]. Karas et al. demonstrated a negative prognostic impact of pre-transplant MRD positivity on EFS and OS in the patient population older than 63 [92]. In a study of Kayser et al., a significantly different OS was observed between pre-transplant MRD negative and MRD-positive cases (estimated 5-year OS 89\% versus $40 \%$, respectively). Other variables such as FLT3-ITD mutational status did not influence this difference [95]. Another interesting conclusion from these studies was related to the role of NPM1-mutated MRD for transplant selection. Notably, patients who achieved a >4-log NPM1-mutated MRD clearance did not benefit from allo-HSCT, but a survival benefit existed for those who failed to achieve clearance $[76,80]$. The clinical implication of these results is far-reaching, not only because NPM1-mutated AML represents the largest uniform subgroup within AML but also because these patients are classified as being of standard risk, for whom the best treatment strategy (transplantation versus chemotherapy) in unclear. It is now possible that the detection of persistent residual NPM1-mutated transcripts may provide additional guidelines for selecting the best treatment approach.

Finally, there may be a role for NPM1-mutated MRD monitoring in predicting relapse after allo-HSCT $[73,79,88,94,97,98]$. Several studies investigated the potential usefulness of NPM1 mutation MRD detection in predicting relapse after allo-HCT. Based on the study of Zhou et al., highly sensitive NGS for NPM1-mutated transcript performed around day 28 after an allo-HSCT predicted a morphologic relapse in 15 of 18 cases (83\%) [97]. Delsing Malmberg et al. used targeted deep sequencing for NPM1 MRD at 3 months after alloHSCT and observed that MRD positive result predicted relapse and was predictive of OS [94]. These early data indicate that patients with NPM1-mutated AML who received an allo-HSCT could benefit from NPM1 MRD monitoring after transplant. Unfortunately, this benefit is decreased by the fact that preventive therapies, such as tapering if immune suppression, donor lymphocyte infusion, and HMA are not yet standardized [80,93,95,99].

Despite the many advantages of NPM1-based MRD monitoring in AML, various challenges exist. NPM1 mutation is stable over the course of disease [57,100,101], and it has been detected at relapse even in patients who experienced more than one relapse, or relapses at extramedullary sites $[57,100,101]$. However, lately it became clear that in rare cases NPM1 mutation may be lost at relapse [72]. The frequency of relapsed AML with undetectable NPM1 mutations has been extremely variable, ranging from $1 \%$ [102] to $25 \%$ in small studies $[103,104]$. Cases that relapsed with undetectable NPM1 mutations were believed to represent a new, therapy-related AML rather than a true relapse [57,72,91]. Later studies outlined the role of clonal evolution behind the phenomenon of lost NPM1 mutation at relapse [72]. Kronke et al. compared paired BM or PB samples collected at diagnosis and at relapse and observed that $D N M T 3 A$ mutations were present in both the primary and the relapse samples in every case with absent NPM1 mutation at relapse [105]. This study strongly suggests the role of a common ancestral clone that acquired a DNMT3A mutation before acquiring an NPM1 mutation, and the NPM1 wild-type/DNMT3A-mutated clone 
gave rise to the relapsed AML [105]. In such cases, RQ-PCR-based NPM1 MRD monitoring will result in negative results [104-106]. Another challenge to the RQ-PCR-based NPM1 MRD monitoring is a potential switch of NPM1 mutation subtype from D to $\mathrm{A}$, a rare scenario that has been recently reported [107].

\section{NPM1 Mutations in Myeloid Neoplasms with $<20 \%$ Blasts}

Since the original discovery of cytoplasmic NPM1 in de novo AML by Falini et al., a strong and specific association between NPM1 mutations and AML has been observed [46]. NPM1 mutations were not observed in any non-myeloid neoplasm. Though less frequent compared with de novo AML, NPM1 mutations have also been observed in secondary AML (defined as progressing from either MDS or myelodysplastic/myeloproliferative neoplasm (MDS/MPN)) with a variable incidence ranging from $4.5 \%$ to $27 \%$ of cases [108-113]. Some of the studies were able to show that NPM1 mutations were commonly detectable during the antecedent MDS phase, while in other cases, the MDS stage lacked the NPM1 mutation [108]. In myeloid neoplasms other than AML, NPM1 mutation has been detected in MDS (2\%) and myelodysplastic/myeloproliferative neoplasms (MDS/MPN) (3\%), with MDS/MPN represented by mainly chronic myelomonocytic leukemia (CMML). Of note, NPM1-mutated MDS most commonly represented MDS with excess blasts (MDS-EB) at diagnosis [114].

Several small retrospective studies reported that the rare cases of MN with NPM1 mutation and $<20 \%$ blasts has been characterized by a rapid progression to AML, usually within 12 months of diagnosis [46,109,115-120]. Early reports suggested that rapid progression of NPM1-mutated MN requires additional mutations, especially FLT3 mutations [117]. Later, it became clear that MN with NPM1 mutation and $<20 \%$ blasts rapidly progress into AML even without additional FLT3 mutations [119-123].

Figure $3 \mathrm{~A}$ shows the morphologic findings of the bone marrow aspirate of a 75-yearold man (Wright Giemsa, 1000 times magnification) who presented with macrocytic anemia (hemoglobin of $7.9 \mathrm{~g} / \mathrm{dL}, \mathrm{MCV} 105.3 \mathrm{fL}$ ) and thrombocytopenia $(48 \mathrm{~K} / \mathrm{uL}$ ). The bone marrow shows dyserythropoiesis and dysgranulopoiesis without increased blasts. The arrows point to erythroid cells with dyserythropoiesis. The circle indicates a dysplastic neutrophil granulocyte (Figure 3A). A diagnosis of myelodysplastic syndrome with multilineage dysplasia was rendered. Routine karyotype analysis showed normal male karyotype. Nextgeneration sequencing showed NPM1 mutation (VAT 45\%) and U2AF1 mutation (VAT $45 \%$ ). Treatment was started with decitabine and venetoclax. Figure $3 \mathrm{~B}$. shows the change in peripheral blood blast percentage over the next two months after diagnosis. Sequential evaluation of the peripheral blood showed the occurrence of circulating blasts 15 days after the initial diagnosis, followed by a rapid increase in blasts percentage, reaching a diagnosis of AML by day 57 (Figure 3B).
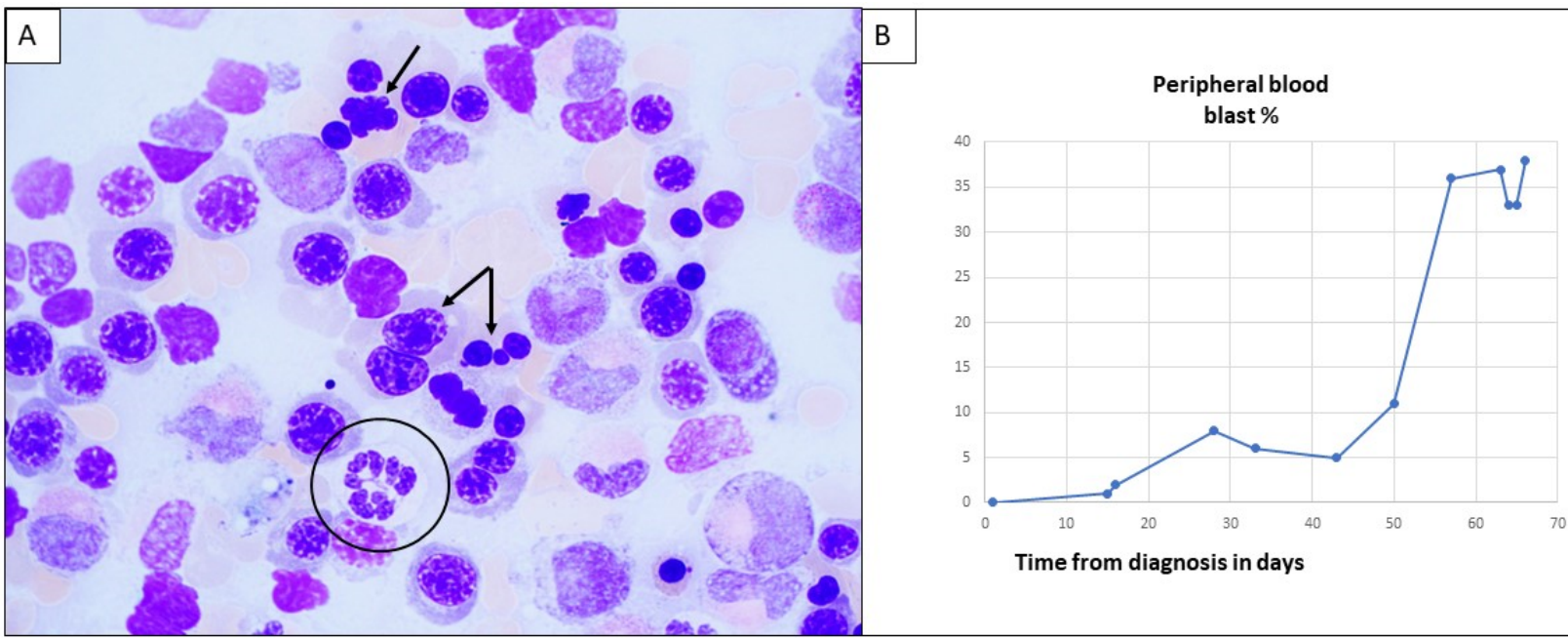

Figure 3. (A,B) A representative case of an NPM1-mutated myeloid neoplasm with less than $20 \%$ blasts. 
A study of 144 CMML patients by Peng et al. described that NPM1-mutated CMML cases were characterized by more severe anemia, higher BM monocyte percentage, a more rapid transformation to AML, and decreased overall survival (OS) then non-NPM1mutated cases, though this study did not reach statistical significance [119]. Another study by Vallapureddy et al. observed some of the same characteristics-notably, more severe anemia in NPM1-mutated CMML patients-and additionally described that DNMT3A and FLT3 mutations were more common, while TET2 and ASXL1 mutations were less common than in CMML cases with no NPM1 mutation [120]. This study also showed a higher risk of blastic transformation of NPM1-mutated CMML (63\%) in comparison with NPM1 wild-type CMML (18\%) at a median of 5 months after initial diagnosis [122].

The largest multicenter cohort of MN with mutated NPM1 and less than 20\% blasts was reported by Patel et al. [123]. Myeloid neoplasms with NPM1 mutations occurred in younger patients and were more commonly associated with a normal karyotype when compared with NPM1 wild-type cases. The mutation landscape was also different, as NPM1-mutated MN more commonly showed DNMT3A and PTPN11 mutations, while mutations of ASXL1, RUNX1, TP53, IDH1, IDH2, FLT3, NRAS, and KRAS mutations were less common than in the NPM1 wild-type neoplasms [123]. When looking at the clinical treatment and outcomes, most patients with NPM1-mutated MN (73\%) were treated with hypomethylating agents (HMA) upfront, and 39\% progressed to AML at a median time of 5.2 months. As a contrast, none of the patients treated with intensive induction chemotherapy progressed to AML. These data suggest that a more intensive chemotherapy upfront may benefit patients with NPM1-mutated MN [123]. Montalban-Bravo et al. reported similar observations in a smaller patient cohort of 31 patients [121]. In their series, all cases showed multilineage dysplasia on morphologic examination, and as such, $61 \%$ of cases were designated as MDS. Overall, the NPM1-mutated MN were younger, had lower hemoglobin levels, and more commonly had a normal karyotype compared with NPM1 wild-type cases. Interestingly, the clearance of mutation after therapy paralleled the disappearance of the dysplastic morphologic features. Complete remission (CR) rates were significantly higher after intensive chemotherapy than after HMA treatment [121]. Not every study shared this observation. Wu et al. reported a small cohort of MDS patients with NPM1 mutation who achieved a favorable outcome after decitabine [124]. At present, a definitive conclusion for the best treatment of NPM1-mutated MN with less than $20 \%$ blasts cannot be drawn. The limited number of data available were derived from small retrospective studies, and they lacked a controlled clinical trial design $[46,121,123]$. Resolution of these controversial issues will require prospective multicenter clinical trials. Overall, due to the poor prognosis in most NPM1-mutated MN patients, HMA-based moderate intensity therapy could be considered inadequate. More intensive therapy could be considered for those NPM1-mutated MN patients who are fit, potentially including induction chemotherapy rather than MDS-directed treatment modalities [46,121,123].

An additional challenge relates to the pathological classification of these uncommon cases of MN showing NPM1 gene mutation and less than 20\% PB and BM blasts. The pathological diagnosis and subclassification has a direct impact on subsequent therapy. It has been long accepted that the presence of certain recurrent cytogenetic abnormalities including $\mathrm{t}(15 ; 17)(\mathrm{q} 22 ; \mathrm{q} 12), \mathrm{t}(8 ; 21)(\mathrm{q} 22 ; \mathrm{q} 22)$, or $\operatorname{inv}(16)(\mathrm{p} 13.1 \mathrm{q} 22) / \mathrm{t}(16 ; 16)(\mathrm{p} 13.1 ; \mathrm{q} 22)$ is enough to establish a diagnosis of AML even in the absence of $20 \%$ blasts [48]. In contrast, the same concept does not apply for the finding of NPM1 gene mutation: myeloid neoplasms with less than $20 \%$ blasts do not meet current criteria for a diagnosis of NPM1-mutated AML. To further complicate the issue, multilineage dysplasia is a common finding in NPM1-mutated AML, yet the presence of NPM1 mutation should have a priority over multilineage dysplasia as a disease-defining criterion [56]. The 2016 WHO classification has declared that NPM1 mutation or biallelic mutation of CEBPA superseded multilineage dysplasia in the diagnostic classification. Based on presence of multilineage dysplasia, a case of NPM1-mutated MN with $<20 \%$ blasts could be easily classified as MDS-EB or MDS/MPN. This diagnosis might sidetrack the patient for a subsequent diagnosis of 
AML with myelodysplasia-related changes (rather than AML with mutated NPM1) at the time when a transformation into AML occurred. Overall, AML with mutated NPM1 may remain underdiagnosed. Forghieri et al. recommended an integrated molecular and immunohistochemical approach by demonstrating NPM1 mutation in the bone marrow and extensive NPMc + staining in more than $20 \%$ blasts in a bone marrow core biopsy to increase a successful diagnosis of AML with mutated NPM1 [118]. Future studies will determine whether NPM1 gene mutation may be sufficient to diagnose NPM1-mutated AML independent of the blast count $[46,118]$. The next revision of the WHO classification of myeloid neoplasm may provide definitive guidelines in this unresolved issue.

\section{Summary}

The availability of new molecular techniques, especially next-generation sequencing, introduced mutation testing into the routine diagnostic arena of myeloid neoplasms. Unfortunately, most of myeloid-associated mutations are not specific to any diagnosis, as they can be seen in individuals without disease and can be present in many different subgroups of disease (MDS, MDS/MPN, AML). Unlike most myeloid mutations, NPM1 is remarkable for its specificity to a subtype of AML that is recognized as a specific diagnostic entity by the current WHO classification of myeloid neoplasms. In addition to its role in diagnostic subclassification, NPM1 mutation determines a subgroup of AML with favorable prognosis, though this is influenced by the presence or absence of certain concomitant mutations, in particular FLT3-ITD and DNMT3. The NPM1 mutation exhibits stability during persistent disease and relapse and has provided an opportunity for MRD testing in this subgroup in AML. Considering that NPM1-mutated AML represents the largest subgroup of AML and is classified as being of standard risk, the detection of persistent residual NPM1-mutated transcripts may provide additional guidelines for decision making between chemotherapy and hematopoietic cell transplantation. The best approach to the pathologic diagnosis and clinical management of myeloid neoplasms with NPM1 mutation and less than $20 \%$ blasts is still unclear. These cases have been characterized with an aggressive clinical course and a rapid-progression AML, and they may benefit from aggressive treatment upfront. Future studies will determine whether NPM1 gene mutation may be sufficient for diagnosing NPM1-mutated AML independent of the blast count.

Funding: This research received no external funding.

Conflicts of Interest: The author of this manuscript has no financial conflict of interest to disclose.

\section{References}

1. Kang, Y.J.; Olson, M.O.; Busch, H. Phosphorylation of acid-soluble proteins in isolated nucleoli of Novikoff hepatoma ascites cells. Effects of divalent cations. J. Biol. Chem. 1974, 249, 5580-5585. [CrossRef]

2. Kang, Y.J.; Olson, M.O.; Jones, C.; Busch, H. Nucleolar phosphoproteins of normal rat liver and Novikoff hepatoma ascites cells. Cancer Res. 1975, 35, 1470-1475. [PubMed]

3. Chan, W.Y.; Liu, Q.R.; Borjigin, J.; Busch, H.; Rennert, O.M.; Tease, L.A.; Chan, P.K. Characterization of the Cdna-Encoding Human Nucleophosmin and Studies of Its Role in Normal and Abnormal Growth. Biochemistry 1989, 28, 1033-1039. [CrossRef] [PubMed]

4. Grisendi, S.; Bernardi, R.; Rossi, M.; Cheng, K.; Khandker, L.; Manova, K.; Pandolfi, P.P. Role of nucleophosmin in embryonic development and tumorigenesis. Nature 2005, 437, 147-153. [CrossRef] [PubMed]

5. Falini, B.; Mecucci, C.; Tiacci, E.; Alcalay, M.; Rosati, R.; Pasqualucci, L.; La Starza, R.; Diverio, D.; Colombo, E.; Santucci, A.; et al. Cytoplasmic nucleophosmin in acute myelogenous leukemia with a normal karyotype. N. Engl. J. Med. 2005, 352, 254-266. [CrossRef]

6. Borer, R.A.; Lehner, C.F.; Eppenberger, H.M.; Nigg, E.A. Major nucleolar proteins shuttle between nucleus and cytoplasm. Cell 1989, 56, 379-390. [CrossRef]

7. Yun, J.P.; Chew, E.C.; Liew, C.T.; Chan, J.Y.; Jin, M.L.; Ding, M.X.; Fai, Y.H.; Li, H.K.; Liang, X.M.; Wu, Q.L. Nucleophosmin/B23 is a proliferate shuttle protein associated with nuclear matrix. J. Cell Biochem. 2003, 90, 1140-1148. [CrossRef] [PubMed]

8. Hingorani, K.; Szebeni, A.; Olson, M.O. Mapping the functional domains of nucleolar protein B23. J. Biol. Chem. 2000, 275, 24451-24457. [CrossRef]

9. Szebeni, A.; Olson, M.O. Nucleolar protein B23 has molecular chaperone activities. Protein Sci. 1999, 8, 905-912. [CrossRef] 
10. Okuwaki, M.; Tsujimoto, M.; Nagata, K. The RNA binding activity of a ribosome biogenesis factor, nucleophosmin/B23, is modulated by phosphorylation with a cell cycle-dependent kinase and by association with its subtype. Mol. Biol. Cell 2002, 13, 2016-2030. [CrossRef] [PubMed]

11. Okuwaki, M.; Matsumoto, K.; Tsujimoto, M.; Nagata, K. Function of nucleophosmin/B23, a nucleolar acidic protein, as a histone chaperone. FEBS Lett. 2001, 506, 272-276. [CrossRef]

12. Swaminathan, V.; Kishore, A.H.; Febitha, K.K.; Kundu, T.K. Human histone chaperone nucleophosmin enhances acetylationdependent chromatin transcription. Mol. Cell. Biol. 2005, 25, 7534-7545. [CrossRef]

13. Falini, B.; Nicoletti, I.; Martelli, M.F.; Mecucci, C. Acute myeloid leukemia carrying cytoplasmic/mutated nucleophosmin (NPMc(+) AML): Biologic and clinical features. Blood 2007, 109, 874-885. [CrossRef]

14. Falini, B.; Bolli, N.; Liso, A.; Martelli, M.P.; Mannucci, R.; Pileri, S.; Nicoletti, I. Altered nucleophosmin transport in acute myeloid leukaemia with mutated NPM1: Molecular basis and clinical implications. Leukemia 2009, 23, 1731-1743. [CrossRef] [PubMed]

15. Wang, D.; Baumann, A.; Szebeni, A.; Olson, M.O. The nucleic acid binding activity of nucleolar protein B23.1 resides in its carboxyl-terminal end. J. Biol. Chem. 1994, 269, 30994-30998. [CrossRef]

16. Savkur, R.S.; Olson, M.O. Preferential cleavage in pre-ribosomal RNA byprotein B23 endoribonuclease. Nucleic Acids Res. 1998, 26, 4508-4515. [CrossRef] [PubMed]

17. Chang, J.H.; Olson, M.O. Structure of the gene for rat nucleolar protein B23. J. Biol. Chem. 1990, 265, 18227-18233. [CrossRef]

18. Wang, D.; Umekawa, H.; Olson, M.O. Expression and subcellular locations of two forms of nucleolar protein B23 in rat tissues and cells. Cell Mol. Biol. Res. 1993, 39, 33-42.

19. Herrera, J.E.; Correia, J.J.; Jones, A.E.; Olson, M.O. Sedimentation analyses of the salt- and divalent metal ion-induced oligomerization of nucleolar protein B23. Biochemistry 1996, 35, 2668-2673. [CrossRef]

20. Namboodiri, V.M.; Akey, I.V.; Schmmmidt-Zachmann, M.S.; Head, J.F.; Akey, C.W. The structure and function of Xenopus NO38-core, a histone chaperone in the nucleolus. Structure 2004, 12, 2149-2160. [CrossRef]

21. Tanaka, M.; Sasaki, H.; Kino, I.; Sugimura, T.; Terada, M. Genes preferentially expressed in embryo stomach are predominantly expressed in gastric cancer. Cancer Res. 1992, 52, 3372-3377.

22. Nozawa, Y.; Van Belzen, N.; Van der Made, A.C.; Dinjens, W.N.; Bosman, F.T. Expression of nucleophosmin/B23 in normal and neoplastic colorectal mucosa. J. Pathol. 1996, 178, 48-52. [CrossRef]

23. Shields, L.B.; Gercel-Taylor, C.; Yashar, C.M.; Wan, T.C.; Katsanis, W.A.; Spinnato, J.A.; Taylor, D.D. Induction of immune responses to ovarian tumor antigens by multiparity. J. Soc. Gynecol. Investig. 1997, 4, 298-304. [CrossRef]

24. Subong, E.N.; Shue, M.J.; Epstein, J.I.; Briggman, J.V.; Chan, P.K.; Partin, A.W. Monoclonal antibody to prostate cancer nuclear matrix protein (PRO:4-216) recognizes nucleophosmin/B23. Prostate 1999, 39, 298-304. [CrossRef]

25. Tsui, K.H.; Cheng, A.J.; Chang, P.; Pan, T.L.; Yung, B.Y. Association of nucleophosmin/B23 mRNA expression with clinical outcome in patients with bladder carcinoma. Urology 2004, 64, 839-844. [CrossRef]

26. Redner, R.L.; Rush, E.A.; Faas, S.; Rudert, W.A.; Corey, S.J. The t(5;17) variant of acute promyelocytic leukemia expresses a nucleophosmin-retinoic acid receptor fusion. Blood 1996, 87, 882-886. [CrossRef]

27. Morris, S.W.; Kirstein, M.N.; Valentine, M.B.; Dittmer, K.G.; Shapiro, D.N.; Saltman, D.L.; Look, A.T. Fusion of a kinase gene, ALK, to a nucleolar protein gene, NPM, in non-Hodgkin's lymphoma. Science 1994, 263, 1281-1284. [CrossRef] [PubMed]

28. Raimondi, S.C.; Dube, I.D.; Valentine, M.B.; Mirro, J.; Jr Watt, H.J.; Larson, R.A.; Bitter, M.A.; Le Beau, M.M.; Rowley, J.D. Clinicopathologic manifestations and breakpoints of the $t(3 ; 5)$ in patients with acute nonlymphocytic leukemia. Leukemia 1989, 3 , $42-47$

29. Yoneda-Kato, N.; Look, A.T.; Kirstein, M.N.; Valentine, M.B.; Raimondi, S.C.; Cohen, K.J.; Carroll, A.J.; Morris, S.W. The $\mathrm{t}(3 ; 5)(\mathrm{q} 25.1 ; \mathrm{q} 34)$ of myelodysplastic syndrome and acute myeloid leukemia produces a novel fusion gene, NPM-MLF1. Oncogene 1996, 12, 265-275.

30. Dergunova, N.; Bulycheva, T.I.; Artemenko, E.G.; Shpakova, A.P.; Pegova, A.N.; Gemjian, E.G.; Dudnik, O.A.; Zatsepina, O.V.; Malashenko, O.S. A major nucleolar protein B23 as a marker of proliferation activity of human peripheral lymphocytes. Immunol. Lett. 2002, 83, 67-72. [CrossRef]

31. Zeller, K.I.; Haggerty, T.J.; Barrett, J.F.; Guo, Q.; Wonsey, D.R.; Dang, C.V. Characterization of nucleophosmin (B23) as a Myc target by scanning chromatin immunoprecipitation. J. Biol. Chem. 2001, 276, 48285-48291. [CrossRef]

32. Boon, K.; Caron, H.N.; van Asperen, R.; Valentijn, L.; Hermus, M.C.; van Sluis, P.; Roobeek, I.; Weis, I.; Voute, P.A.; Schwab, M.; et al. N-myc enhances the expression of a large set of genes functioning in ribosome biogenesis and protein synthesis. $E M B O J$. 2001, 20, 1383-1393. [CrossRef]

33. Takemura, M.; Sato, K.; Nishio, M.; Akiyama, T.; Umekawa, H.; Yoshida, S. Nucleolar protein B23.1 binds to retinoblastoma protein and synergistically stimulates DNA polymerase alpha activity. J. Biochem. 1999, 125, 904-909. [CrossRef]

34. Dumbar, T.S.; Gentry, G.A.; Olson, M.O. Interaction of nucleolar phosphoprotein B23 with nucleic acids. Biochemistry 1989, 28, 9495-9501. [CrossRef]

35. Prestayko, A.W.; Klomp, G.R.; Schmoll, D.J.; Busch, H. Comparison of proteins of ribosomal subunits and nucleolar preribosomal particles from Novikoff hepatoma ascites cells by two-dimensional polyacrylamide gel electrophoresis. Biochemistry 1974, 13, 1945-1951. [CrossRef] [PubMed]

36. Olson, M.O.; Wallace, M.O.; Herrera, A.H.; Marshall-Carlson, L.; Hunt, R.C. Preribosomal ribonucleoprotein particles are a major component of a nucleolar matrix fraction. Biochemistry 1986, 25, 484-491. [CrossRef] [PubMed] 
37. Kondo, T.; Minamino, N.; Nagamura-Inoue, T.; Matsumoto, M.; Taniguchi, T.; Tanaka, N. Identification and characterization of nucleophosmin/B23/numatrin which binds the anti-oncogenic transcription factor IRF-1 and manifests oncogenic activity. Oncogene 1997, 15, 1275-1281. [CrossRef] [PubMed]

38. Bertwistle, D.; Sugimoto, M.; Sherr, C.J. Physical and functional interactions of the Arf tumor suppressor protein with nucleophosmin/B23. Mol. Cell. Biol. 2004, 24, 985-996. [CrossRef]

39. Kuo, M.L.; den Besten, W.; Bertwistle, D.; Roussel, M.F.; Sherr, C.J. N-terminal polyubiquitination and degradation of the Arf tumor suppressor. Genes Dev. 2004, 18, 1862-1874. [CrossRef]

40. Brady, S.N.; Yu, Y.; Maggi, L.B.; Weber, J.D. ARF impedes NPM/B23 shuttling in an Mdm2-sensitive tumor suppressor pathway. Mol. Cell. Biol. 2004, 24, 9327-9338. [CrossRef]

41. Kurki, S.; Peltonen, K.; Latonen, L.; Kiviharju, T.M.; Ojala, P.M.; Meek, D.; Laiho, M. Nucleolar protein NPM interacts with HDM2 and protects tumor suppressor protein p53 from HDM2-mediated degradation. Cancer Cell 2004, 5, 465-475. [CrossRef]

42. Oren, M. Regulation of the p53 tumor suppressor protein. J. Biol. Chem. 1999, 274, 36031-36034. [CrossRef]

43. Gao, H.; Jin, S.Q.; Song, Y.M.; Fu, M.; Wang, M.R.; Liu, Z.H.; Wu, M.; Zhan, Q.M. B23 regulates GADD45a nuclear translocation and contributes to GADD45a-induced cell cycle G(2)-M arrest. J. Biol. Chem. 2005, 280, 10988-10996. [CrossRef]

44. Wu, M.H.; Chang, J.H.; Yung, B.Y. Resistance to UV-induced cell-killing in nucleophosmin/B23 over-expressed NIH 3T3 fibroblasts: Enhancement of DNA repair and up-regulation of PCNA in association with nucleophosmin/B23 over-expression. Carcinogenesis 2002, 23, 93-100. [CrossRef]

45. Okuda, M.; Horn, H.F.; Tarapore, P.; Tokuyama, Y.; Smulian, A.G.; Chan, P.K.; Knudsen, E.S.; Hofmann, I.A.; Snyder, J.D.; Bove, K.E.; et al. Nucleophosmin/B23 is a target of CDK2/cyclin E in centrosome duplication. Cell 2000, 103, 127-140. [CrossRef]

46. Falini, B.; Brunetti, L.; Sportoletti, P.; Martelli, M.P. NPM1-mutated acute myeloid leukemia: From bench to bedside. Blood 2020, 136, 1707-1721. [CrossRef]

47. Grimwade, D.; Ivey, A.; Huntly, B.J.P. Molecular landscape of acute myeloid leukemia in younger adults and its clinical relevance. Blood 2016, 127, 29-41. [CrossRef] [PubMed]

48. Arber, D.A.; Brunning, R.D.; Le Beau, M.M.; Falini, B.; Vardiman, J.W.; Porwit, A.; Thiele, J.; Foucar, K.; Dohner, H.; Bloomfield, C.D. Acute myeloid leukaemia with recurrent genetic abnormalities. In WHO CLassification of Tumours of Haematopoietic and Lymphoid Tissue; Swerdlow, S.H., Campo, E., Harris, N.L., Jaffe, E.S., Pileri, S.A., Stein, H., Thiele, J., Arber, D.A., Hasserjian, R.P., Le Beau, M.M., et al., Eds.; International Agency for Research on Cancer: Lyon, France, 2017; pp. 141-142.

49. Verhaak, R.G.W.; Goudswaard, C.S.; van Putten, W.; Bijl, M.A.; Sanders, M.A.; Hugens, W.; Uitterlinden, A.G.; Erpelinck, C.A.J.; Delwel, R.; Lowenberg, B.; et al. Mutations in nucleophosmin (NPM1) in acute myeloid leukemia (AML): Association with other gene abnormalities and previously established gene expression signatures and their favorable prognostic significance. Blood 2005 106, 3747-3754. [CrossRef] [PubMed]

50. Nakagawa, M.; Kameoka, Y.; Suzuki, R. Nucleophosmin in acute myelogenous leukemia. N. Engl. J. Med. 2005, 352, 1819-1820.

51. Falini, B.; Bolli, N.; Shan, J.; Martelli, M.P.; Liso, A.; Pucciarini, A.; Bigerna, B.; Pasqualucci, L.; Mannucci, R.; Rosati, R.; et al. Both carboxy-terminus NES motif and mutated tryptophan(s) are crucial for aberrant nuclear export of nucleophosmin leukemic mutants in NPMc(+) AML. Blood 2006, 107, 4514-4523. [CrossRef] [PubMed]

52. Grisendi, S.; Pandolfi, P.P. NPM mutations in acute myelogenous leukemia. N. Engl. J. Med. 2005, 352, 291-292. [CrossRef]

53. Schnittger, S.; Schoch, C.; Kern, W.; Mecucci, C.; Tschulik, C.; Martelli, M.F.; Haferlach, T.; Hiddemann, W.; Falini, B. Nucleophosmin gene mutations are predictors of favorable prognosis in acute myelogenous leukemia with a normal karyotype. Blood 2005 106, 3733-3739. [CrossRef] [PubMed]

54. Dohner, K.; Schlenk, R.F.; Habdank, M.; Scholl, C.; Rucker, F.G.; Corbacioglu, A.; Bullinger, L.; Frohling, S.; Dohner, H. Mutant nucleophosmin (NPM1) predicts favorable prognosis in younger adults with acute myeloid leukemia and normal cytogenetics: Interaction with other gene mutations. Blood 2005, 106, 3740-3746. [CrossRef]

55. Diaz-Beya, M.; Rozman, M.; Pratcorona, M.; Torrebadell, M.; Camos, M.; Aguilar, J.L.; Esteve, J. The prognostic value of multilineage dysplasia in de novo acute myeloid leukemia patients with intermediate-risk cytogenetics is dependent on NPM1 mutational status. Blood 2010, 116, 6147-6148. [CrossRef] [PubMed]

56. Falini, B.; Macijewski, K.; Weiss, T. Multilineage dysplasia has no impact on biologic, clinicopathologic, and prognostic features of AML with mutated nucleophosmin (NPM1) (vol 115, pg 3776, 2010). Blood 2010, 116, 1017.

57. Falini, B.; Martelli, M.P.; Bolli, N.; Sportoletti, P.; Liso, A.; Tiacci, E.; Haferlach, T. Acute myeloid leukemia with mutated nucleophosmin (NPM1): Is it a distinct entity? Blood 2011, 117, 1109-1120. [CrossRef] [PubMed]

58. Hollein, A.; Meggendorfer, M.; Dicker, F.; Jeromin, S.; Nadarajah, N.; Kern, W.; Haferlach, C.; Haferlach, T. NPM1 mutated AML can relapse with wild-type NPM1: Persistent clonal hematopoiesis can drive relapse. Blood Adv. 2018, 2, 3118-3125. [CrossRef]

59. Forghieri, F.; Comoli, P.; Marasca, R.; Potenza, L.; Luppi, M. Minimal/Measurable Residual Disease Monitoring in NPM1-Mutated Acute Myeloid Leukemia: A Clinical Viewpoint and Perspectives. Int. J. Mol. Sci. 2018, 19, 3492. [CrossRef]

60. Brown, P.; McIntyre, E.; Rau, R.; Meshinchi, S.; Lacayo, N.; Dahl, G.; Alonzo, T.A.; Chang, M.; Arceci, R.J.; Small, D. The incidence and clinical significance of nucleophosmin mutations in childhood AML. Blood 2007, 110, 979-985. [CrossRef]

61. Schlenk, R.F.; Dohner, K.; Krauter, J.; Frohling, S.; Corbacioglu, A.; Bullinger, L.; Habdank, M.; Spath, D.; Morgan, M.; Benner, A.; et al. Mutations and treatment outcome in cytogenetically normal acute myeloid leukemia. N. Engl. J. Med. 2008, 358, 1909-1918. [CrossRef] 
62. Thiede, C.; Koch, S.; Creutzig, E.; Steudel, C.; Illmer, T.; Schaich, M.; Ehninger, G. Prevalence and prognostic impact of NPM1 mutations in 1485 adult patients with acute myeloid leukemia (AML). Blood 2006, 107, 4011-4020. [CrossRef] [PubMed]

63. Haferlach, C.; Mecucci, C.; Schnittger, S.; Kohlmann, A.; Mancini, M.; Cuneo, A.; Testoni, N.; Rege-Cambrin, G.; Santucci, A.; Vignetti, M.; et al. AML with mutated NPM1 carrying a normal or aberrant karyotype show overlapping biologic, pathologic, immunophenotypic, and prognostic features. Blood 2009, 114, 3024-3032. [CrossRef] [PubMed]

64. Micol, J.B.; Boissel, N.; Renneville, A.; Castaigne, S.; Gardin, C.; Preudhomme, C.; Dombret, H. The role of cytogenetic abnormalities in acute myeloid leukemia with NPM1 mutations and no FLT3 internal tandem duplication. Blood 2009, 114, 4601-4602. [CrossRef] [PubMed]

65. Gale, R.E.; Green, C.; Allen, C.; Mead, A.J.; Burnett, A.K.; Hills, R.K.; Linch, D.C. Medical Research Council Adult Leukaemia Working P: The impact of FLT3 internal tandem duplication mutant level, number, size, and interaction with NPM1 mutations in a large cohort of young adult patients with acute myeloid leukemia. Blood 2008, 111, 2776-2784. [CrossRef]

66. Pratcorona, M.; Brunet, S.; Nomdedeu, J.; Ribera, J.M.; Tormo, M.; Duarte, R.; Escoda, L.; Guardia, R.; Queipo de Llano, M.P.; Salamero, O.; et al. Favorable outcome of patients with acute myeloid leukemia harboring a low-allelic burden FLT3-ITD mutation and concomitant NPM1 mutation: Relevance to post-remission therapy. Blood 2013, 121, 2734-2738. [CrossRef] [PubMed]

67. Schlenk, R.F.; Kayser, S.; Bullinger, L.; Kobbe, G.; Casper, J.; Ringhoffer, M.; Held, G.; Brossart, P.; Lubbert, M.; Salih, H.R.; et al. Differential impact of allelic ratio and insertion site in FLT3-ITD-positive AML with respect to allogeneic transplantation. Blood 2014, 124, 3441-3449. [CrossRef]

68. Becker, H.; Marcucci, G.; Maharry, K.; Radmacher, M.D.; Mrozek, K.; Margeson, D.; Whitman, S.P.; Wu, Y.Z.; Schwind, S.; Paschka, P.; et al. Favorable prognostic impact of NPM1 mutations in older patients with cytogenetically normal de novo acute myeloid leukemia and associated gene- and microRNA-expression signatures: A Cancer and Leukemia Group B study. J. Clin. Oncol. 2010, 28, 596-604. [CrossRef]

69. Loghavi, S.; Zuo, Z.; Ravandi, F.; Kantarjian, H.M.; Bueso-Ramos, C.; Zhang, L.; Singh, R.R.; Patel, K.P.; Medeiros, L.J.; Stingo, F.; et al. Clinical features of de novo acute myeloid leukemia with concurrent DNMT3A, FLT3 and NPM1 mutations. J. Hematol. Oncol. 2014, 7, 74. [CrossRef]

70. Ossenkoppele, G.; Schuurhuis, G.J. MRD in AML: Does it already guide therapy decision-making? Hematol. Am. Soc. Hematol Educ. Program 2016, 2016, 356-365. [CrossRef] [PubMed]

71. Gorello, P.; Cazzaniga, G.; Alberti, F.; Dell'Oro, M.G.; Gottardi, E.; Specchia, G.; Roti, G.; Rosati, R.; Martelli, M.F.; Diverio, D.; et al. Quantitative assessment of minimal residual disease in acute myeloid leukemia carrying nucleophosmin (NPM1) gene mutations. Leukemia 2006, 20, 1103-1108. [CrossRef]

72. Papadaki, C.; Dufour, A.; Seibl, M.; Schneider, S.; Bohlander, S.K.; Zellmeier, E.; Mellert, G.; Hiddemann, W.; Spiekermann, K. Monitoring minimal residual disease in acute myeloid leukaemia with NPM1 mutations by quantitative PCR: Clonal evolution is a limiting factor. Br. J. Haematol. 2009, 144, 517-523. [CrossRef]

73. Schnittger, S.; Kern, W.; Tschulik, C.; Weiss, T.; Dicker, F.; Falini, B.; Haferlach, C.; Haferlach, T. Minimal residual disease levels assessed by NPM1 mutation-specific RQ-PCR provide important prognostic information in AML. Blood 2009, 114, $2220-2231$. [CrossRef] [PubMed]

74. Hubmann, M.; Kohnke, T.; Hoster, E.; Schneider, S.; Dufour, A.; Zellmeier, E.; Fiegl, M.; Braess, J.; Bohlander, S.K.; Subklewe, M.; et al. Molecular response assessment by quantitative real-time polymerase chain reaction after induction therapy in NPM1mutated patients identifies those at high risk of relapse. Haematologica 2014, 99, 1317-1325. [CrossRef] [PubMed]

75. Alizad Ghandforoush, N.; Chahardouli, B.; Rostami, S.; Ghadimi, H.; Ghasemi, A.; Alimoghaddam, K.; Ghavamzadeh, A.; Nadali, F. Evaluation of Minimal Residual Disease in Acute Myeloid Leukemia with NPM1 Marker. Int. J. Hematol. Oncol. Stem. Cell Res. 2016, 10, 147-152.

76. Balsat, M.; Renneville, A.; Thomas, X.; de Botton, S.; Caillot, D.; Marceau, A.; Lemasle, E.; Marolleau, J.P.; Nibourel, O.; Berthon, C.; et al. Postinduction Minimal Residual Disease Predicts Outcome and Benefit From Allogeneic Stem Cell Transplantation in Acute Myeloid Leukemia With NPM1 Mutation: A Study by the Acute Leukemia French Association Group. J. Clin. Oncol. 2017, 35, 185-193. [CrossRef]

77. Patkar, N.; Kodgule, R.; Kakirde, C.; Raval, G.; Bhanshe, P.; Joshi, S.; Chaudhary, S.; Badrinath, Y.; Ghoghale, S.; Kadechkar, S.; et al. Clinical impact of measurable residual disease monitoring by ultradeep next generation sequencing in NPM1 mutated acute myeloid leukemia. Oncotarget 2018, 9, 36613-36624. [CrossRef]

78. Schuurhuis, G.J.; Heuser, M.; Freeman, S.; Bene, M.C.; Buccisano, F.; Cloos, J.; Grimwade, D.; Haferlach, T.; Hills, R.K.; Hourigan, C.S.; et al. Minimal/measurable residual disease in AML: A consensus document from the European LeukemiaNet MRD Working Party. Blood 2018, 131, 1275-1291. [CrossRef]

79. Shayegi, N.; Kramer, M.; Bornhauser, M.; Schaich, M.; Schetelig, J.; Platzbecker, U.; Rollig, C.; Heiderich, C.; Landt, O.; Ehninger, G.; et al. The level of residual disease based on mutant NPM1 is an independent prognostic factor for relapse and survival in AML. Blood 2013, 122, 83-92. [CrossRef] [PubMed]

80. Hantel, A.; Stock, W.; Kosuri, S. Molecular Minimal Residual Disease Testing in Acute Myeloid Leukemia: A Review for the Practicing Clinician. Clin. Lymphoma Myeloma Leuk 2018, 18, 636-647. [CrossRef]

81. Dohner, H.; Estey, E.; Grimwade, D.; Amadori, S.; Appelbaum, F.R.; Buchner, T.; Dombret, H.; Ebert, B.L.; Fenaux, P.; Larson, R.A.; et al. Diagnosis and management of AML in adults: 2017 ELN recommendations from an international expert panel. Blood 2017, 129, 424-447. [CrossRef] 
82. Gu, X.; Ebrahem, Q.; Mahfouz, R.Z.; Hasipek, M.; Enane, F.; Radivoyevitch, T.; Rapin, N.; Przychodzen, B.; Hu, Z.; Balusu, R.; et al. Leukemogenic nucleophosmin mutation disrupts the transcription factor hub that regulates granulomonocytic fates. J. Clin. Investig. 2018, 128, 4260-4279. [CrossRef]

83. Patel, S.S.; Kuo, F.C.; Gibson, C.J.; Steensma, D.P.; Soiffer, R.J.; Alyea, E.P.; 3rd Chen, Y.A.; Fathi, A.T.; Graubert, T.A.; Brunner, A.M.; et al. High NPM1-mutant allele burden at diagnosis predicts unfavorable outcomes in de novo AML. Blood 2018, 131, 2816-2825. [CrossRef]

84. Tomlinson, B.; Lazarus, H.M. Enhancing acute myeloid leukemia therapy-Monitoring response using residual disease testing as a guide to therapeutic decision-making. Expert Rev. Hematol. 2017, 10, 563-574. [CrossRef] [PubMed]

85. Ravandi, F.; Walter, R.B.; Freeman, S.D. Evaluating measurable residual disease in acute myeloid leukemia. Blood Adv. 2018, 2, 1356-1366. [CrossRef]

86. Chou, W.C.; Tang, J.L.; Wu, S.J.; Tsay, W.; Yao, M.; Huang, S.Y.; Huang, K.C.; Chen, C.Y.; Huang, C.F.; Tien, H.F. Clinical implications of minimal residual disease monitoring by quantitative polymerase chain reaction in acute myeloid leukemia patients bearing nucleophosmin (NPM1) mutations. Leukemia 2007, 21, 998-1004. [CrossRef] [PubMed]

87. Barragan, E.; Pajuelo, J.C.; Ballester, S.; Fuster, O.; Cervera, J.; Moscardo, F.; Senent, L.; Such, E.; Sanz, M.A.; Bolufer, P. Minimal residual disease detection in acute myeloid leukemia by mutant nucleophosmin (NPM1): Comparison with WT1 gene expression Clin. Chim. Acta 2008, 395, 120-123. [CrossRef] [PubMed]

88. Bacher, U.; Badbaran, A.; Fehse, B.; Zabelina, T.; Zander, A.R.; Kroger, N. Quantitative monitoring of NPM1 mutations provides a valid minimal residual disease parameter following allogeneic stem cell transplantation. Exp. Hematol. 2009, 37, 135-142. [CrossRef] [PubMed]

89. Dvorakova, D.; Racil, Z.; Jeziskova, I.; Palasek, I.; Protivankova, M.; Lengerova, M.; Razga, F.; Mayer, J. Monitoring of minimal residual disease in acute myeloid leukemia with frequent and rare patient-specific NPM1 mutations. Am. J. Hematol. 2010, 85, 926-929. [CrossRef]

90. Kristensen, T.; Moller, M.B.; Friis, L.; Bergmann, O.J.; Preiss, B. NPM1 mutation is a stable marker for minimal residual disease monitoring in acute myeloid leukaemia patients with increased sensitivity compared to WT1 expression. Eur. J. Haematol. 2011, 87, 400-408. [CrossRef]

91. Kronke, J.; Schlenk, R.F.; Jensen, K.O.; Tschurtz, F.; Corbacioglu, A.; Gaidzik, V.I.; Paschka, P.; Onken, S.; Eiwen, K.; Habdank, M.; et al. Monitoring of minimal residual disease in NPM1-mutated acute myeloid leukemia: A study from the German-Austrian acute myeloid leukemia study group. J. Clin. Oncol. 2011, 29, 2709-2716. [CrossRef]

92. Karas, M.; Steinerova, K.; Lysak, D.; Hrabetova, M.; Jungova, A.; Sramek, J.; Jindra, P.; Polivka, J.; Holubec, L. Pre-transplant Quantitative Determination of NPM1 Mutation Significantly Predicts Outcome of Allogeneic Hematopoietic Stem Cell Transplantation in Patients with Normal Karyotype AML in Complete Remission. Anticancer Res. 2016, 36, 5487-5498. [CrossRef] [PubMed]

93. Bill, M.; Grimm, J.; Jentzsch, M.; Kloss, L.; Goldmann, K.; Schulz, J.; Beinicke, S.; Hantschel, J.; Cross, M.; Vucinic, V.; et al. Digital droplet PCR-based absolute quantification of pre-transplant NPM1 mutation burden predicts relapse in acute myeloid leukemia patients. Ann. Hematol. 2018, 97, 1757-1765. [CrossRef] [PubMed]

94. Delsing Malmberg, E.; Johansson Alm, S.; Nicklasson, M.; Lazarevic, V.; Stahlman, S.; Samuelsson, T.; Lenhoff, S.; Asp, J.; Ehinger, M.; Palmqvist, L.; et al. Minimal residual disease assessed with deep sequencing of NPM1 mutations predicts relapse after allogeneic stem cell transplant in AML. Leuk Lymphoma 2019, 60, 409-417. [CrossRef] [PubMed]

95. Kayser, S.; Benner, A.; Thiede, C.; Martens, U.; Huber, J.; Stadtherr, P.; Janssen, J.W.; Rollig, C.; Uppenkamp, M.J.; Bochtler, T.; et al Pretransplant NPM1 MRD levels predict outcome after allogeneic hematopoietic stem cell transplantation in patients with acute myeloid leukemia. Blood Cancer J. 2016, 6, e449. [CrossRef] [PubMed]

96. Getta, B.M.; Devlin, S.M.; Levine, R.L.; Arcila, M.E.; Mohanty, A.S.; Zehir, A.; Tallman, M.S.; Giralt, S.A.; Roshal, M. Multicolor Flow Cytometry and Multigene Next-Generation Sequencing Are Complementary and Highly Predictive for Relapse in Acute Myeloid Leukemia after Allogeneic Transplantation. Biol. Blood Marrow Transpl. 2017, 23, 1064-1071. [CrossRef] [PubMed]

97. Zhou, Y.; Othus, M.; Walter, R.B.; Estey, E.H.; Wu, D.; Wood, B.L. Deep NPM1 Sequencing Following Allogeneic Hematopoietic Cell Transplantation Improves Risk Assessment in Adults with NPM1-Mutated AML. Biol. Blood Marrow Transpl. 2018, 24, 1615-1620. [CrossRef] [PubMed]

98. Stahl, T.; Badbaran, A.; Kroger, N.; Klyuchnikov, E.; Zabelina, T.; Zeschke, S.; Schafhausen, P.; Schultz, W.; Asenova, S.; Smirnova A.; et al. Minimal residual disease diagnostics in patients with acute myeloid leukemia in the post-transplant period: Comparison of peripheral blood and bone marrow analysis. Leuk Lymphoma 2010, 51, 1837-1843. [CrossRef] [PubMed]

99. Lee, C.J.; Savani, B.N.; Mohty, M.; Gorin, N.C.; Labopin, M.; Ruggeri, A.; Schmid, C.; Baron, F.; Esteve, J.; Giebel, S.; et al Post-remission strategies for the prevention of relapse following allogeneic hematopoietic cell transplantation for high-risk acute myeloid leukemia: Expert review from the Acute Leukemia Working Party of the European Society for Blood and Marrow Transplantation. Bone Marrow Transpl. 2019, 54, 519-530.

100. Meloni, G.; Mancini, M.; Gianfelici, V.; Martelli, M.P.; Foa, R.; Falini, B. Late relapse of acute myeloid leukemia with mutated NPM1 after eight years: Evidence of NPM1 mutation stability. Haematologica 2009, 94, 298-300. [CrossRef]

101. Bolli, N.; Galimberti, S.; Martelli, M.P.; Tabarrini, A.; Roti, G.; Mecucci, C.; Martelli, M.F.; Petrini, M.; Falini, B. Cytoplasmic nucleophosmin in myeloid sarcoma occurring 20 years after diagnosis of acute myeloid leukaemia. Lancet Oncol. 2006, 7, 350-352. [CrossRef] 
102. Ivey, A.; Hills, R.K.; Simpson, M.A.; Jovanovic, J.V.; Gilkes, A.; Grech, A.; Patel, Y.; Bhudia, N.; Farah, H.; Mason, J.; et al. Assessment of Minimal Residual Disease in Standard-Risk AML. N. Engl. J. Med. 2016, 374, 422-433. [CrossRef] [PubMed]

103. Thol, F.; Kolking, B.; Damm, F.; Reinhardt, K.; Klusmann, J.H.; Reinhardt, D.; von Neuhoff, N.; Brugman, M.H.; Schlegelberger, B.; Suerbaum, S.; et al. Next-generation sequencing for minimal residual disease monitoring in acute myeloid leukemia patients with FLT3-ITD or NPM1 mutations. Genes Chromosomes Cancer 2012, 51, 689-695. [CrossRef] [PubMed]

104. Martinez-Losada, C.; Serrano-Lopez, J.; Serrano-Lopez, J.; Noguera, N.I.; Garza, E.; Piredda, L.; Lavorgna, S.; Consalvo, M.A.I.; Ottone, T.; Alfonso, V.; et al. Clonal genetic evolution at relapse of favorable-risk acute myeloid leukemia with NPM1 mutation is associated with phenotypic changes and worse outcomes. Haematologica 2018, 103, e400-e403. [CrossRef] [PubMed]

105. Kronke, J.; Bullinger, L.; Teleanu, V.; Tschurtz, F.; Gaidzik, V.I.; Kuhn, M.W.; Rucker, F.G.; Holzmann, K.; Paschka, P.; KappSchworer, S.; et al. Clonal evolution in relapsed NPM1-mutated acute myeloid leukemia. Blood 2013, 122, 100-108. [CrossRef]

106. Sockel, K.; Wermke, M.; Radke, J.; Kiani, A.; Schaich, M.; Bornhauser, M.; Ehninger, G.; Thiede, C.; Platzbecker, U. Minimal residual disease-directed preemptive treatment with azacitidine in patients with NPM1-mutant acute myeloid leukemia and molecular relapse. Haematologica 2011, 96, 1568-1570. [CrossRef]

107. Bacher, U.; Porret, N.; Joncourt, R.; Sanz, J.; Aliu, N.; Wiedemann, G.; Jeker, B.; Banz, Y.; Pabst, T. Pitfalls in the molecular follow up of NPM1 mutant acute myeloid leukemia. Haematologica 2018, 103, e486-e488. [CrossRef]

108. Schnittger, S.; Bacher, U.; Haferlach, C.; Alpermann, T.; Dicker, F.; Sundermann, J.; Kern, W.; Haferlach, T. Characterization of NPM1-mutated AML with a history of myelodysplastic syndromes or myeloproliferative neoplasms. Leukemia 2011, 25, 615-621. [CrossRef]

109. Courville, E.L.; Wu, Y.; Kourda, J.; Roth, C.G.; Brockmann, J.; Muzikansky, A.; Fathi, A.T.; de Leval, L.; Orazi, A.; Hasserjian, R.P. Clinicopathologic analysis of acute myeloid leukemia arising from chronic myelomonocytic leukemia. Mod. Pathol. 2013, 26, 751-761. [CrossRef]

110. Fernandez-Mercado, M.; Yip, B.H.; Pellagatti, A.; Davies, C.; Larrayoz, M.J.; Kondo, T.; Perez, C.; Killick, S.; McDonald, E.J.; Odero, M.D.; et al. Mutation patterns of 16 genes in primary and secondary acute myeloid leukemia (AML) with normal cytogenetics. PLOS ONE 2012, 7, e42334.

111. Lindsley, R.C.; Mar, B.G.; Mazzola, E.; Grauman, P.V.; Shareef, S.; Allen, S.L.; Pigneux, A.; Wetzler, M.; Stuart, R.K.; Erba, H.P.; et al. Acute myeloid leukemia ontogeny is defined by distinct somatic mutations. Blood 2015, 125, 1367-1376. [CrossRef]

112. Wang, S.Y.; Cheng, W.Y.; Mao, Y.F.; Zhu, Y.M.; Liu, F.J.; Ma, T.T.; Shen, Y. Genetic alteration patterns and clinical outcomes of elderly and secondary acute myeloid leukemia. Hematol. Oncol. 2019, 37, 456-463. [CrossRef]

113. Badar, T.; Szabo, A.; Sallman, D.; Komrojki, R.; Lancet, J.; Padron, E.; Song, J.; Hussaini, M.O. Interrogation of molecular profiles can help in differentiating between MDS and AML with MDS-related changes. Leuk Lymphoma 2020, 61, 1418-1427. [CrossRef]

114. Forghieri, F.; Nasillo, V.; Paolini, A.; Bettelli, F.; Pioli, V.; Giusti, D.; Gilioli, A.; Colasante, C.; Acquaviva, G.; Riva, G.; et al. NPM1-Mutated Myeloid Neoplasms with <20\% Blasts: A Really Distinct Clinico-Pathologic Entity? Int. J. Mol. Sci. 2020, $21,8975$. [CrossRef] [PubMed]

115. Caudill, J.S.; Sternberg, A.J.; Li, C.Y.; Tefferi, A.; Lasho, T.L.; Steensma, D.P. C-terminal nucleophosmin mutations are uncommon in chronic myeloid disorders. Br. J. Haematol. 2006, 133, 638-641. [CrossRef]

116. Oki, Y.; Jelinek, J.; Beran, M.; Verstovsek, S.; Kantarjian, H.M.; Issa, J.P. Mutations and promoter methylation status of NPM1 in myeloproliferative disorders. Haematologica 2006, 91, 1147-1148.

117. Bains, A.; Luthra, R.; Medeiros, L.J.; Zuo, Z. FLT3 and NPM1 mutations in myelodysplastic syndromes: Frequency and potential value for predicting progression to acute myeloid leukemia. Am. J. Clin. Pathol. 2011, 135, 62-69. [CrossRef]

118. Forghieri, F.; Paolini, A.; Morselli, M.; Bigliardi, S.; Bonacorsi, G.; Leonardi, G.; Coluccio, V.; Maccaferri, M.; Fantuzzi, V.; Faglioni, L.; et al. NPM1 mutations may reveal acute myeloid leukemia in cases otherwise morphologically diagnosed as myelodysplastic syndromes or myelodysplastic/myeloproliferative neoplasms. Leuk Lymphoma 2015, 56, 3222-3226. [CrossRef]

119. Peng, J.; Zuo, Z.; Fu, B.; Oki, Y.; Tang, G.; Goswami, M.; Priyanka, P.; Muzzafar, T.; Medeiros, L.J.; Luthra, R.; et al. Chronic myelomonocytic leukemia with nucleophosmin (NPM1) mutation. Eur. J. Haematol. 2016, 96, 65-71. [CrossRef] [PubMed]

120. Vallapureddy, R.; Lasho, T.L.; Hoversten, K.; Finke, C.M.; Ketterling, R.; Hanson, C.; Gangat, N.; Tefferi, A.; Patnaik, M.M. Nucleophosmin 1 (NPM1) mutations in chronic myelomonocytic leukemia and their prognostic relevance. Am J. Hematol. 2017, 92, E614-E618. [CrossRef] [PubMed]

121. Montalban-Bravo, G.; Kanagal-Shamanna, R.; Sasaki, K.; Patel, K.; Ganan-Gomez, I.; Jabbour, E.; Kadia, T.; Ravandi, F.; DiNardo, C.; Borthakur, G.; et al. NPM1 mutations define a specific subgroup of MDS and MDS/MPN patients with favorable outcomes with intensive chemotherapy. Blood Adv. 2019, 3, 922-933. [CrossRef] [PubMed]

122. Hwang, S.M.; Kim, S.M.; Nam, Y.; Kim, J.; Kim, S.; Ahn, Y.O.; Park, Y.; Yoon, S.S.; Shin, S.; Kwon, S.; et al. Targeted sequencing aids in identifying clonality in chronic myelomonocytic leukemia. Leuk Res. 2019, 84, 106190. [CrossRef] [PubMed]

123. Patel, S.S.; Ho, C.; Ptashkin, R.N.; Sadigh, S.; Bagg, A.; Geyer, J.T.; Xu, M.L.; Prebet, T.; Mason, E.F.; Seegmiller, A.C.; et al. Clinicopathologic and genetic characterization of nonacute NPM1-mutated myeloid neoplasms. Blood Adv. 2019, 3, 1540-1545. [CrossRef] [PubMed]

124. Wu, L.; Li, X.; Xu, F.; Wu, D.; He, Q.; Song, L.; Xiao, C.; Zhao, Y.; Zhang, Z.; Guo, J.; et al. NPM1 mutation with DNMT3A wild type defines a subgroup of MDS with particularly favourable outcomes after decitabine therapy. Br. J. Haematol. 2020, 189, 982-984. [CrossRef] [PubMed] 